\title{
Photodetectors for Weak Signal Conditions from Au/Cu co-doped ZnO
}

\section{Imen Ben Elkamel ( $\square$ imenbenelkamel@gmail.com )}

University of Sousse Higher School of Science and Technology of Hammam Sousse: Universite de Sousse Ecole Superieure des Sciences et de la Technologie de Hammam Sousse

\section{Nejeh Hamdaoui}

University of Sousse: Universite de Sousse

\section{Amine Mezni}

Taif University

\section{Ridha Ajjel}

University of Sousse Higher School of Science and Technology of Hammam Sousse: Universite de Sousse Ecole Superieure des Sciences et de la Technologie de Hammam Sousse

\section{Lotfi Beji}

Qassim University

\section{Research Article}

Keywords: polyol synthesis, Au/Cu-doped ZnO , Ultraviolet (UV), photodetectors (PD), X-ray diffraction (XRD)

Posted Date: April 29th, 2021

DOI: https://doi.org/10.21203/rs.3.rs-331709/v1

License: (c) (i) This work is licensed under a Creative Commons Attribution 4.0 International License. Read Full License

Version of Record: A version of this preprint was published at Optical and Quantum Electronics on July 10th, 2021. See the published version at https://doi.org/10.1007/s11082-021-03038-z. 


\title{
Photodetectors for weak signal conditions from $\mathrm{Au} / \mathrm{Cu}$ co-doped $\mathrm{ZnO}$
}

Imen Ben Elkamel ${ }^{\mathrm{a},}$, Nejeh Hamdaoui ${ }^{\mathrm{b}}$, Amine Meznic, Ridha Ajjel ${ }^{\mathrm{a}}$, Lotfi Beji ${ }^{\mathrm{d}}$

${ }^{a}$ University of Sousse, Laboratary of Energy and Materials (LR11ES34), Higher School of Science and Technology of Hammam, Street Lamine Abessi, 4011, Hammam Sousse, Tunisia.

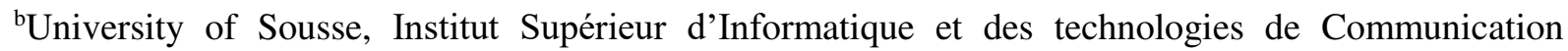
ISITCOM, Gp1, 4011, Hammam Sousse, Tunisia.

${ }^{\mathrm{c}}$ Department of Chemistry, College of Science, Taif University, P.O. Box 11099, Taif 21944, Saudi Arabia.

${ }^{\mathrm{d}}$ Department of physics, College of science and Arts at Ar Rass, Qassim University, P. O. Box 53, Ar Rass 51921, Saudi Arabia.

*Corresponding author: Email:imenbenelkamel@gmail.com

\begin{abstract}
Here, we have used a simple method for polyol synthesis, analysis, and testing of $\mathrm{Au} / \mathrm{Cu}-$ doped $\mathrm{ZnO}$ Ultraviolet (UV) photodetectors (PD). Our results are reported and discussed by $\mathrm{X}$-ray diffraction (XRD) to ensure that the manufactured samples show a hexagonal wurtzite $\mathrm{ZnO}$ structure. Transmission electron microscopy (TEM) confirmed the nanoparticle growth in the hexagonal sample on the surface, which is the key to improving the light response. Our prepared UV PD Au/Cu codoped $\mathrm{ZnO}$ showed a rapid time at a power density of $7.6 \mathrm{~mW}$. the highest responsivity of $\mathrm{R}=575 \mathrm{~mA} / \mathrm{W}$ and sensitivity $10^{3}$ obtained at $7.6 \mathrm{~mW}$ with an applied voltage of $1 \mathrm{~V}$. Our results demonstrate the obvious substitution of $\mathrm{Au}$ and $\mathrm{Cu}$ in $\mathrm{ZnO}$, thereby improving the UV-sensing light response.
\end{abstract}

\section{Introduction}

Photodetectors are important for a range of applications such as smart sensors, biological sensors, satellite communication, and pharmaceutical analyses [1-3]. $\mathrm{ZnO}$ is considered to be an important material for future UV PD due to its interesting characteristics, such as optical transparency, a wide band gap of $3.37 \mathrm{eV}$, and a large exciton binding energy of $60 \mathrm{meV}$ [4, 5]. For photodetector applications, pure $\mathrm{ZnO}$ nanoparticles are n-type semiconductors, and their optical and electrical properties are inferior and more unstable without doping elements [6]. There are many techniques to improve the physical properties of $\mathrm{ZnO}$-based UV PD materials, such as doping/co-doping, sol-gel co-precipitation, etc. [7-10]. Generally, doping is 
commonly used to improve the electrical and optical properties of $\mathrm{ZnO}$. Despite the use of single-doped $\mathrm{ZnO}$, electrical and optical properties cannot be improved simultaneously [11, 12]. Therefore, co-doping is considered to be an effective method to improve both electrical and optical properties. In recent years, noble metals ( $\mathrm{Pt}, \mathrm{Au}, \mathrm{Ag}$, and $\mathrm{Cu}$ ) and other nanoparticles have distinctive properties in terms of light, electricity, heat, and catalysis [13, 14]. They have very good application prospects in the fields of micro-nano photoelectric devices and biosensors, which have attracted great attention and extensive research by research groups all over the world. Moreover, nanoparticles generate surface plasmon resonance (SPR) effects due to the quasi-free electrons in the conduction band under the excitation light of a certain wavelength, thus generating surface plasmon absorption peaks in the visible to near-infrared region. So, light is trapped and enhanced close to the Au NPs, resulting in an increase in the amount of photocurrent in the $\mathrm{ZnO}[10,25]$. In other words, the enhanced light absorption of the ZnO Nps by the SPR of the Au NPs results an improvement in photoresponsivity.

Nowadays, UV PDs based ZnO may be ameliorated by doping of noble metals such as Ag, $\mathrm{Au}$, and Pt [15-17]. The noble metal Au is very used as a doping element because of its larger ionic radii, high solubility, and minimal orbital energy [18]. Consequently, $\mathrm{Cu}$ and $\mathrm{Au}$ are considered as the most suitable doping elements as compared to other researchers used codoping only with a transition metal. So, $\mathrm{Au} / \mathrm{Cu}$ codoping $\mathrm{ZnO}$ may improve the UV photoresponse and responsivity also the presence of $\mathrm{Au}$ improved the response time which is recently a key parameter for UV PD. Our work reports a high photoresponse UV PD-based $\mathrm{Au} / \mathrm{Cu}$ codoped $\mathrm{ZnO}$ which is elaborated by polyol process. Up to our knowledge, $\mathrm{Au} / \mathrm{Cu}$ codoped ZnO UV PD has not been reported.

\section{Experimental details}

Undoped $\mathrm{ZnO}, \mathrm{Cu}$ doped $\mathrm{ZnO}$, and $\mathrm{Au} / \mathrm{Cu}$ codoped $\mathrm{ZnO}$ were fabricated using the polyol medium. To prepare our samples, zinc acetate dihydrate $\left(\mathrm{Zn}\left(\mathrm{CH}_{3} \mathrm{COO}\right)_{2} .2 \mathrm{H}_{2} \mathrm{O}\right)$, hydrogen tetrachloroaurate (III): trihydrate $\left(\mathrm{HAuCl}_{4} .3 \mathrm{H}_{2} \mathrm{O}\right)$, copper acetate tetrahydrate $(\mathrm{Cu}$ $\left.\left(\mathrm{CH}_{3} \mathrm{COO}\right)_{2} .4 \mathrm{H}_{2} \mathrm{O}\right)$ and polyol (1,2-propanediol (PEG), diethylene glycol (DEG)) are used in their appropriate stoichiometric ratio. The obtained solution is mixed at $50{ }^{\circ} \mathrm{C}$ for $30 \mathrm{~min}$. The concentration of $\mathrm{Cu}$ and $\mathrm{Au}$ is $5 \mathrm{at} \%$ and 3at\%, respectively. The total amount of metal ( $\mathrm{Zn}$ and dopant metal $\mathrm{Cu}$ ) was fixed at $0.5 \mathrm{M}$.

The structural and morphological characterization of our samples was performed by X-ray diffraction (XRD) (diffractometer using cobalt radiation at $1.7890 \mathrm{~A}^{\circ}$ ) and transmission 
electron microscope (TEM) (JEOL 2011 microscope operating at $100 \mathrm{kV}$ ). The optical properties were analyzed by diffuse reflection spectroscopy (DRS). FTIR spectra in the range of 4000-400 cm-1 were obtained by infrared spectrophotometer (two spectroscopic FTIR spectrometers of Perkin Elmer). Then, the 200 SCS Keithley instrument was used to study the optical response of the device under ultraviolet light with a wavelength of $375 \mathrm{~nm}$ under different bias voltages.

\section{Results and discussion}

\section{Structural and morphological analysis}

Figure 1shows TEM images of the pure $\mathrm{ZnO}$ nanoparticles and $\mathrm{Au} / \mathrm{Cu}$ co-doped $\mathrm{ZnO}$. The images display that pure $\mathrm{ZnO}$ nanoparticles are nearly spherical having regular smooth surfaces. After codoping, the smooth surface is still retained with little aggregation. It is also very obvious that the nanoparticles have very clear and well-defined grain boundaries with a prominent effect on the physical properties of the samples [31]. Moreover, particle size distribution is also calculated. For the undoped $\mathrm{ZnO}$ nanoparticles, the average particle size ranges from 4 to $16 \mathrm{~nm}$. The average particle size distribution is from 12 to $20 \mathrm{~nm}$ for the codoping sample.

Fig. 2 presents the $\mathrm{XRD}$ profiles of undoped $\mathrm{ZnO}$ and $\mathrm{Au} / \mathrm{Cu}$ codoped $\mathrm{ZnO}$. The diffraction peaks corresponded to (100) (002) (101) (102) (110) (103) (200) and (112). These peaks can be indexed to the $\mathrm{ZnO}$ hexagonal Wurtzite structure and it is demonstrated that the doping $\mathrm{Cu}$ and $\mathrm{Au}$ did not change the structure of $\mathrm{ZnO}$. We can observe that there aren't secondary phase related to $\mathrm{Cu}$ and $\mathrm{Au}$. So, $\mathrm{Cu}^{2+}$ and $\mathrm{Au}^{3+}$ are successfully substituted in the $\mathrm{ZnO}$ lattice. The interplanar spacing $\left(\mathrm{d}_{\mathrm{hkl}}\right)$ value was determined by the following relation [13]

$\frac{1}{d^{2}}=\frac{4}{3} \frac{h^{2}+h k+k^{2}}{a^{2}}+\frac{l^{2}}{c^{2}}$

Where $\mathrm{h}, \mathrm{k}$, and $\mathrm{l}$ are Miller's indices.

The volume unit cell was calculated using the relation [6]

$V=0.866 \times a^{2} \times c$

The values of various structural parameters such as a, c, c/a ratio, degree of distortion $\mathrm{R}$, and internal parameter $\mathrm{u}$ were estimated following ozgin and Morkoç [11]. These obtained values 
have been shown in table 1 . It is indicated that the different structural parameters increase after doping.

The average crystallite size D of the nanoparticles was calculated using Debye Scherrer's relation [6]

$D=\frac{0.9 \lambda}{\beta \cos \theta}$

Where $\mathrm{k}, \lambda, \Theta$ and $\beta$ are constant, the wavelength of XRD radiation, Bragg angle and full width at half maximum, respectively. The obtained value of pure $\mathrm{ZnO}$ and codoped $\mathrm{ZnO}$ are 22 and $26 \mathrm{~nm}$, respectively. This increase of crystallite size is associated with the mismated ionic radius of $\mathrm{Cu}^{2+}, \mathrm{Au}^{3+}$ and $\mathrm{Zn}^{2+}$.

\section{Optical properties}

Fig. 3 indicates the FTIR spectra of undoped $\mathrm{ZnO}$ and $\mathrm{Au} / \mathrm{Cu}$ codoped $\mathrm{ZnO}$ Nps. The position and number of absorption bonds depend on the crystal structure, the particle morphology, and the chemical composition [20]. A broad absorption peak at $3451 \mathrm{~cm}^{-1}$ is associated to hydroxyl(-OH) group indicating the presence of water molecules. Then, the peak at $1385 \mathrm{~cm}^{-1}$ is due to the asymmetric stretching vibrations of the $\mathrm{C}=\mathrm{O}$ group owing to lewis acidity [21]. While the peak at $1616 \mathrm{~cm}^{-1}$ is associated to the symmetric stretching modes of acetate (COO) group owing to Brosted acidity [21]. The band at $2346 \mathrm{~cm}^{-1}$ confirmed the presence of $\mathrm{CO}_{2}$ molecules. It is observed a strong IR band at $434 \mathrm{~cm}^{-1}$ which corresponded to the vibration of $\mathrm{Zn}-\mathrm{O}$ [22]. the peaks observed at $671 \mathrm{~cm}^{-1}$ could be related to the stretching vibrations of $\mathrm{Zn}$ $\mathrm{O}$ bonds octahedral arrangements. The $\mathrm{ZnO}$ bonds on octahedral arrangements are much lower than the tetrahedral coordination. The peaks at $671 \mathrm{~cm}^{-1}$ highlight that codoping do not influence band associated to octahedral coordination [23]. So, $\mathrm{Au} / \mathrm{Cu}$ ions are substituted only at tetrahedral coordination in the $\mathrm{ZnO}$ lattice structure.

Fig. 4 indicates the UV-Vis-DRS of pure and $\mathrm{Au} / \mathrm{Cu}$ codoped $\mathrm{ZnO}$. The absorption edges of $\mathrm{Au} / \mathrm{Cu}$ codoped $\mathrm{ZnO}$ are slightly red-shifted than the pure $\mathrm{ZnO}$. This shifting is associated to the doping of $\mathrm{Au}$ and $\mathrm{Cu}$ into $\mathrm{ZnO}$. The data obtained from the diffuse reflectance spectra were fitted with the Kubelka-Munk function [19] and are presented in figure 4. The optical band gaps are determined to be $3.24 \mathrm{eV}$ and $3.26 \mathrm{eV}$ for undoped $\mathrm{ZnO}$ and $\mathrm{Au} / \mathrm{Cu}$ codoped $\mathrm{ZnO}$, respectively. With doping, new occupied electronic states near the conduction band that 
are considered as donor levels are responsible for the widening of the optical band gap according to the Burstein-Moss theory[17].

For the diffuse reflectance spectra, the other significant features in the visible region are shown in figure 4(a). the absorption bonds at 566, 611 and $660 \mathrm{~nm}$ are associated to the d-d crystal field transitions 4A2(F)->2A1(G), 4A2(F)->4T1 $(\mathrm{P})$ and 4A2(F)->2E1(G), respectively.

\section{I-V characteristics}

Figure 5 shows the $\mathrm{I}-\mathrm{V}$ characteristics of pure $\mathrm{ZnO}$ and $\mathrm{Au} / \mathrm{Cu}$ co-doped $\mathrm{ZnO}$ Nps. The electrical characteristics were determined under two conditions: by scanning the voltage from $-5 \mathrm{~V}$ to $5 \mathrm{~V}$. Under dark and UV illumination, the device exhibited non-linear behavior, showing Schottky contact (schema 5b). When $1 \mathrm{~V}$ is applied across this device, interestingly, both the dark $\left(6 \times 10^{-8} \mathrm{~A}\right)$ and photocurrent $\left(4 \times 10^{-7} \mathrm{~A}\right)$ increased significantly from the codoped device. Further increment of photocurrent in Au Nps based device is believed to be due to the localized surface plasmon resonance (LSPR) effects such as near-field enhancement, transfer of plasmon resonance energy and strong absorption light from plasmonic NPs to ZnO [24-26]. Under UV illumination, the electrons in Au NPs get excited to its surface and are easily transferred to the $\mathrm{ZnO}$. Also, the photogenerated holes move towards the NPs and reduce the recombination rate, which results in enhanced photoresponse [27-30].

\section{UV photoresponse measurements}

Fig. 6 shows five cycles of the UV photoresponse of $\mathrm{Au} / \mathrm{Cu}$ codoped $\mathrm{ZnO} \mathrm{Nps}$, which were performed to demonstrate the stability of UV PD. It is noted that the photoresponse values are the same as the UV illumination in all repetition cycles and recovery well at the baseline. Moreover, the responsivity (R) and sensitivity (S) are the important parameters for UV PD which was determined by using the following equation [31]

$$
\begin{aligned}
& R=\frac{I_{p h}}{P_{o p t}}(\mathrm{~A} / \mathrm{W}) \\
& S=\frac{I_{\text {light }}-I_{\text {dark }}}{I_{\text {dark }}} \times 100
\end{aligned}
$$

Where $\mathrm{I}_{\mathrm{ph}}, \mathrm{I}_{\mathrm{dark}}$ and $\mathrm{P}_{\mathrm{opt}}$ are the photocurrent, the dark current and the incident optical power. 
Figure 7 shows a graph of sensitivity and responsivity as a function of power density. For our device, the observed sensitivity is up to level $10^{3}$. As the value of power increase, the sensitivity of our fabricated device decrease since there is domination of drain current in the on-state by photogenerated charge carrier, but under illumination drain current is just associated by photogenerated charge carrier in the off state. Moreover, the responsivity decreased with the increase of power and it has a maximum of $575 \mathrm{~mA} / \mathrm{W}$ at $1 \mathrm{~V}$. As the nature of the metal/semiconductor interface and the incident light strongly affect the surface plasmon effect of the nanoparticles, changes in the wavelength of the incident light can improve the photoelectric detection performance [32].

The detectivity, which indicates the smallest detectable signal, is also calculated by $D^{*}=$ $\frac{(s \Delta f) 1}{2} / N E P$, where $\Delta \mathrm{f}$ is the electrical bandwidth of the signal and NEP indicates the noise equivalent power. By hypothesizing that the dark current is the major source of short noise, we get $D^{*}=\left(R S^{1 / 2}\right) /\left(2 q I_{\text {dark }}\right)^{1 / 2}[33]$ and then $\mathrm{D}^{*}$ of the detector is estimated to be $3.66 \times$ $10^{12}$ Jones.

Upon UV illumination, our device shows an improved photoresponse as compared to the results found in the literature [34-36]. This enhancement of photoresponse is attributed to the LSPR effects of Au Nps. After incorporation of Au Nps in $\mathrm{ZnO}$, local Schottky barriers at the interface of $\mathrm{Au}$ and $\mathrm{ZnO}$ rise the width of the depletion region. As result, these Schottky barriers lead to a smaller dark current and an effective separation of photogenerated holes from electrons.

The linear dynamic range (LDR, quoted in $\mathrm{dB}$ ) is calculated as the following relation:

$L D R=20 \log \left(\frac{I_{p h}}{I_{d}}\right)$

It is defined to describe the signal-to-noise ratio. The LDR of our device is $50 \mathrm{~dB}$. A high LDR indicates that the ratio of photocurrent to dark current is quite large, and the signal-tonoise ratio is also large. At $1 \mathrm{~V}$ bias voltage, the output current of our device drops 3 orders of magnitude and increases almost 4 orders of magnitude with off/on UV light, respectively, within $0.5 \mathrm{~s}$, demonstrating the quick response time of this device.

The impulse response of $\mathrm{Au} / \mathrm{Cu}$ co-doped $\mathrm{ZnO} \mathrm{PD}$ has six cycles, as shown in Figure 6a, which also proves the stability and repeatability of our device. The single cycle of the impulse response in Figure $6 \mathrm{~b}$ indicates a rise time of $1.82 \mathrm{~s}$ and a decay time of $1.02 \mathrm{~s}$. This is much faster than a pure $\mathrm{ZnO}$ film with a rise and decay times of $18 \mathrm{~s}$ and $56 \mathrm{~s}$, respectively [36]. Since the rise and fall times depend largely on the light intensity, the response time can be 
shortened by increasing the light intensity [37]. The performance of our device is compared with other co-doped $\mathrm{ZnO}$-based PD UVs in the literature. Importantly, response times as short as $1.82 \mathrm{~s}$ are better than most other material-based PDs. The high detectivity of $3.66 \times 10^{12}$ Jones is higher than that $\left(1.07 \times 10^{11}\right)$ of $\mathrm{ZnO}$ based device, demonstrates the high performance of photodetection under a weak light condition [38-41]. Notably, our photodetector proves as superior as detectivity and responsivity of traditional UV detectors and excellent external quantum efficiency exceed $60 \%$.

Table II shows the collected data of our $\mathrm{Au} / \mathrm{Cu}$ codoped $\mathrm{ZnO}$ sample as compared to results found in the literature. The performances of our devices indicate the possibility of using $\mathrm{Au} / \mathrm{Cu}$ codoped $\mathrm{ZnO}$ nanoparticles to develop photodetectors that demonstrate improved performance using a simple, and low cost elaboration method.

\section{UV detection mechanism}

Fig. 8 shows the mechanism of UV photodetection and charge transfer process for $\mathrm{ZnO}$ nanoparticles based UV PD without and with $\mathrm{Au} / \mathrm{Cu}$ codoped ions. In the absence of UV illumination, the large surface area of $\mathrm{ZnO}$ nanoparticles adsorbs the oxygen molecules in the atmosphere and kept at grains and their grains boundaries (Fig. 8). these oxygen molecules capture free electrons from n-type $\mathrm{ZnO} \mathrm{Nps}$.

So, oxygen ions $\left(\mathrm{O}_{2}^{-}, \mathrm{O}^{-}\right.$and $\left.\mathrm{O}^{2-}\right)$ are produced on the surface by the following chemical reactions

$O_{2}(g)+e^{-} \rightarrow O^{-2}(a d s)$

$O_{2}(g)+e^{-} \rightarrow 20^{-}(a d s)$

$O^{-}(g)+e^{-} \rightarrow O^{-2}(a d s)$

From these reactions, we can conclude that the free charge carrier concentration is minimized by removing electrons from the $\mathrm{ZnO}$ surface, thus, there is a creation of low conductivity depletion near the surface of $\mathrm{ZnO}$ Nps (Fig. 8a).

Upon UV illumination, electrons- holes were migrated to the surface of $\mathrm{ZnO}$ to interact which the adsorbed oxygen ions, with leads to the desorption of oxygen by the surface. This phenomenon can be explained by the following chemical reaction

$h^{+}+O^{-2} \rightarrow O_{2}($ ads $)$ 
Consequently, the free electrons concentration increase and the depletion layer width decrease.

To understand, the mechanism of improved photoresponse in $\mathrm{ZnO}$ nanoparticles UV PD codoped with $\mathrm{Au} / \mathrm{Cu}$ ions, an energy band diagram for the device was also presented (Fig.8b). Under the illumination, the electrons are excited from the valence band to the conduction band of $\mathrm{ZnO}$, leaving the identical quantity of holes in the valence band. The newly shaped Fermi energy of the $\mathrm{Au} / \mathrm{ZnO}$ is lower than the energy level of the bottom of the conduction band of $\mathrm{ZnO}$, so the photoexcited electrons would be transferred from $\mathrm{ZnO}$ to $\mathrm{Au}$, driven by the energy difference to reduce carrier recombination. The mechanism of photoresponses for $\mathrm{Au} / \mathrm{ZnO}$ is noble metal as a medium for storing and releasing electrons through a Fermi level between semiconductor and metal nanoparticle, the quantum rate of the photogenerated electron transfer process can be enhanced by promoting the interfacial charge transfer in these conforming systems. At a similar time, attributable to the change of the metal particles, that causes the surface plasmon oscillation to be improved, causes the local electric field change just about it. This local field successfully causes the interaction between the electrical field and also the metal cluster. In the meantime, because of SPR excitation, Au nanoparticles absorb the resonant photons to get hot electrons, and hot electrons were transferred to the conduction band of $\mathrm{ZnO}$. Owing to the presence of an applied electric field, the recombination rate of photogenerated electrons and holes is greatly reduced. So, Au can affect as an electron sink, reducing the recombination rate of the electron-hole pairs, thereby increasing the directional separation efficiency of the photogenerated charge.

\section{Conclusion}

In summary, we have successfully prepared $\mathrm{Au} / \mathrm{Cu}$ co-doped $\mathrm{ZnO}$ UV PD using a polyol process. Our samples were analyzed by various methods and investigated in detail. Structural analysis shows that our sample has a polycrystalline wurtzite $\mathrm{ZnO}$ structure oriented along the c-axis (002). The morphological analysis shows that Au Nps has been dispersed on the surface of $\mathrm{ZnO}$ Nps particles with medium uniform size. In addition, with the co-doping of $\mathrm{Au}$ and $\mathrm{Cu}$, the optical band decreased from $3.24 \mathrm{Ev}(\mathrm{ZnO})$ to $3.26 \mathrm{eV}(\mathrm{Au} / \mathrm{Cu}$ co-doped $\mathrm{ZnO}$ ). Compared with the literature attributed to the LSPR mechanism, we obtain a fast response time. The highest responsivity and sensitivity $\left(\mathrm{R}=575 \mathrm{~mA} / \mathrm{W}\right.$ and $\left.\mathrm{S}=10^{3}\right)$ are obtained at $7.6 \mathrm{~mW}$ for bias voltage at $1 \mathrm{~V}$. Our results showed $\mathrm{Au} / \mathrm{Cu}$ codoped $\mathrm{ZnO}$ has a 
good crystalline structure, rapid response, highest responsivity, and gain. This new structure is suitable for UV photodetectors.

\section{ACKNOWLEDGMENTS}

Taif University Researchers Supporting Project number (TURSP-2020/28), Taif University, Taif, Saudi Arabia.

\section{References}

[1] Rosenbaum, L. (2020). Facing Covid-19 in Italy-ethics, logistics, and therapeutics on the epidemic's front line. New England Journal of Medicine, 382(20), 1873-1875.

[2] Chu, J., Wang, F., Yin, L., Lei, L., Yan, C., Wang, F., ... \& Xiong, J. (2017). High-performance ultraviolet photodetector based on a few-layered 2D NiPS3 nanosheet. Advanced Functional Materials, 27(32), 1701342.

[3] Liu, H., Zhang, Z., Hu, L., Gao, N., Sang, L., Liao, M., ... \& Fang, X. (2014). New UV-A Photodetector Based on Individual Potassium Niobate Nanowires with High Performance. Advanced Optical Materials, 2(8), 771-778.

[4] Dib, K., Trari, M., \& Bessekhouad, Y. (2020). (S, C) co-doped ZnO properties and enhanced photocatalytic activity. Applied Surface Science, 505, 144541.

[5] Zhang, H., Li, W., Qin, G., Ruan, H., Huang, Z., Wu, F., ... \& Fang, L. (2019). Role of zinc interstitial defects in indium and magnesium codoped $\mathrm{ZnO}$ transparent conducting films. Applied Surface Science, 492, 392-398.

[6] Elkamel, I. B., Hamdaoui, N., Mezni, A., \& Ajjel, R. (2020). Enhancement of dielectric properties of $\mathrm{Ni}$ and $\mathrm{Co}$ doped $\mathrm{ZnO}$ due to the oxygen vacancies for $\mathrm{UV}$ photosensors application. Physica E: Low-dimensional Systems and Nanostructures, 119, 114031.

[7] Hamdaoui, N., Elkamel, I. B., Mezni, A., Ajjel, R., \& Beji, L. (2019). Highly efficient, low cost, and stable self-powered UV photodetector based on $\mathrm{Co} 2+$ : $\mathrm{ZnO} / \mathrm{Sn}$ diluted magnetic semiconductor nanoparticles. Ceramics International, 45(14), 17729-17736.

[8] Elkamel, I. B., Hamdaoui, N., Mezni, A., Ajjel, R., \& Beji, L. (2018). High responsivity and 1/f noise of an ultraviolet photodetector based on $\mathrm{Ni}$ doped $\mathrm{ZnO}$ nanoparticles. RSC advances, 8(56), 32333-32343. 
[9] He, G. H., Zhou, H., Shen, H., Lu, Y. J., Wang, H. Q., Zheng, J. C., .. \& Shen, D. Z. (2017). Photodetectors for weak-signal detection fabricated from $\mathrm{ZnO}$ :(Li, N) films. Applied Surface Science, 412, 554-558.

[10] Duta, M., Mihaiu, S., Munteanu, C., Anastasescu, M., Osiceanu, P., Marin, A., ... \& Gartner, M. (2015). Properties of In-N codoped p-type ZnO nanorods grown through a twostep chemical route. Applied Surface Science, 344, 196-204.

[11] Sharma, D., \& Jha, R. (2017). Transition metal (Co, Mn) co-doped ZnO nanoparticles: effect on structural and optical properties. Journal of Alloys and Compounds, 698, 532-538.

[12] Ali, R. N., Naz, H., Li, J., Zhu, X., Liu, P., \& Xiang, B. (2018). Band gap engineering of transition metal $(\mathrm{Ni} / \mathrm{Co})$ codoped in zinc oxide $(\mathrm{ZnO})$ nanoparticles. Journal of Alloys and Compounds, 744, 90-95.

[13] Ben Elkamel, I., Hamdaoui, N., Mezni, A., \& Ajjel, R. (2020). Photoconduction, dielectric and photoluminescence properties of $\mathrm{Cu} 2+: \mathrm{ZnO}$ nanoparticles elaborated by a polyol method. Phase Transitions, 93(4), 388-406.

[14] Elkamel, I. B., Hamdaoui, N., Mezni, A., Ajjel, R., \& Beji, L. (2019). Synthesis and characterization of $\mathrm{Cu}$ doped $\mathrm{ZnO}$ nanoparticles for stable and fast response UV photodetector at low noise current. Journal of Materials Science: Materials in Electronics, 30(10), 9444-9454.

[15] Elemike, E. E., Onwudiwe, D. C., Wei, L., Chaogang, L., \& Zhiwei, Z. (2019). Noble metal-semiconductor nanocomposites for optical, energy and electronics applications. Solar Energy Materials and Solar Cells, 201, 110106.

[16] Mahanti, M., \& Basak, D. (2012). Highly enhanced UV emission due to surface plasmon resonance in $\mathrm{Ag}-\mathrm{ZnO}$ nanorods. Chemical Physics Letters, 542, 110-116.

[17] Kumar, A., Dixit, T., Palani, I. A., Nakamura, D., Higashihata, M., \& Singh, V. (2017). Utilization of surface plasmon resonance of $\mathrm{Au} / \mathrm{Pt}$ nanoparticles for highly photosensitive $\mathrm{ZnO}$ nanorods network based plasmon field effect transistor. Physica E: Low-dimensional Systems and Nanostructures, 93, 97-104. 
[18] Lupan, O., Postica, V., Pauporté, T., Hoppe, M., \& Adelung, R. (2019). UV nanophotodetectors: A case study of individual Au-modified $\mathrm{ZnO}$ nanowires. Sensors and Actuators A: Physical, 296, 400-408.

[19] Sharma, D., \& Jha, R. (2017). Analysis of structural, optical and magnetic properties of Fe/Co co-doped ZnO nanocrystals. Ceramics International, 43(11), 8488-8496.

[20] Zhang, H., Li, W., Qin, G., Ruan, H., Huang, Z., Wu, F., ... \& Fang, L. (2019). Role of zinc interstitial defects in indium and magnesium codoped $\mathrm{ZnO}$ transparent conducting films. Applied Surface Science, 492, 392-398.

[21] Fang, D., Lin, K., Xue, T., Cui, C., Chen, X., Yao, P., \& Li, H. (2014). Influence of Al doping on structural and optical properties of $\mathrm{Mg}-\mathrm{Al}$ co-doped $\mathrm{ZnO}$ thin films prepared by sol-gel method. Journal of alloys and compounds, 589, 346-352.

[22] Gowrishankar, S., Balakrishnan, L., Balasubramanian, T., \& Gopalakrishnan, N. (2013). Fabrication of n-Zn1- xGaxO/p-(ZnO) 1-x (GaP) x thin films and homojunction. Materials Science and Engineering: B, 178(1), 31-38.

[23] Kumar, A. G., Li, X., Du, Y., Geng, Y., \& Hong, X. (2020). UV-photodetector based on heterostructured $\mathrm{ZnO} /(\mathrm{Ga}, \mathrm{Ag})$-co-doped $\mathrm{ZnO}$ nanorods by cost-effective two-step process. Applied Surface Science, 509, 144770.

[24] Chang, T. J., \& Hsueh, T. J. (2020). A NO2 Gas Sensor with a TiO2 Nanoparticles/ZnO/MEMS-Structure that is Produced Using Ultrasonic Wave Grinding Technology. Journal of The Electrochemical Society, 167(2), 027521.

[25] Hsu, C. L., Jhang, B. Y., Kao, C., \& Hsueh, T. J. (2018). UV-illumination and Aunanoparticles enhanced gas sensing of p-type Na-doped $\mathrm{ZnO}$ nanowires operating at room temperature. Sensors and Actuators B: Chemical, 274, 565-574.

[26] Young, S. J., \& Chu, Y. L. (2021). Hydrothermal Synthesis and Improved $\mathrm{CH}_{3} \mathrm{OH}-$ Sensing Performance of $\mathrm{ZnO}$ Nanorods With Adsorbed Au NPs. IEEE Transactions on Electron Devices, 68(4), 1886-1891.

[27] Hu, K., Teng, F., Zheng, L., Yu, P., Zhang, Z., Chen, H., \& Fang, X. (2017). Binary response $\mathrm{Se} / \mathrm{ZnO}$ p-n heterojunction UV photodetector with high on/off ratio and fast speed. Laser \& Photonics Reviews, 11(1), 1600257. 
[28] Djamil, R., Aicha, K., Souifi, A., \& Fayçal, D. (2017). Effect of annealing time on the performance of tin oxide thin films ultraviolet photodetectors. Thin Solid Films, 623, 1-7.

[29] Agarwal, H., Khandelwal, S., Dey, S., Hu, C., \& Chauhan, Y. S. (2015). Analytical modeling of flicker noise in halo implanted MOSFETs. IEEE Journal of the Electron Devices Society, 3(4), 355-360.

[30] Hsu, C. L., Wu, H. Y., Fang, C. C., \& Chang, S. P. (2018). Solution-processed UV and visible photodetectors based on $\mathrm{Y}$-doped $\mathrm{ZnO}$ nanowires with $\mathrm{TiO} 2$ nanosheets and $\mathrm{Au}$ nanoparticles. ACS Applied Energy Materials, 1(5), 2087-2095.

[31] Rana, V. S., Rajput, J. K., Pathak, T. K., \& Purohit, L. P. (2020). Influence of N2 flow rate on UV photodetection properties of sputtered $\mathrm{p}-\mathrm{ZnO} / \mathrm{n}-\mathrm{Si}$ heterojuctions. Colloids and Surfaces A: Physicochemical and Engineering Aspects, 586, 124103.

[32] Ning, Y., Zhang, Z., Teng, F., \& Fang, X. (2018). Novel transparent and self-powered UV photodetector based on crossed $\mathrm{ZnO}$ nanofiber array homojunction. Small, 14(13), 1703754.

[33] Yuan, H., Xu, M., Dong, C., Ma, J., \& Wang, X. (2019). Mechanistic insights into magnetic and gas sensing properties of (F, Na)-codoped $\mathrm{ZnO}$ nanocrystals by roomtemperature photoluminescence. Applied Surface Science, 496, 143511.

[34] Pascariu, P., Tudose, I. V., Suchea, M., Koudoumas, E., Fifere, N., \& Airinei, A. (2018). Preparation and characterization of $\mathrm{Ni}$, $\mathrm{Co}$ doped $\mathrm{ZnO}$ nanoparticles for photocatalytic applications. Applied Surface Science, 448, 481-488.

[35] Jin, H. J., Oh, S. H., \& Park, C. B. (2008). Unidirectional variation of lattice constants of Al-N-codoped $\mathrm{ZnO}$ films by RF magnetron sputtering. Applied Surface Science, 254(7), 2207-2210.

[36] Gozeh, B. A., Karabulut, A., Yildiz, A., \& Yakuphanoglu, F. (2018). Solar light responsive $\mathrm{ZnO}$ nanoparticles adjusted using $\mathrm{Cd}$ and $\mathrm{La} \mathrm{Co}$-dopant photodetector. Journal of Alloys and Compounds, 732, 16-24.

[37] Yakout, S. M. (2018). Pure and Gd-based Li, Na, Mn or Fe codoped ZnO nanoparticles: insights into the magnetic and photocatalytic properties. Solid State Sciences, 83, 207-217. 
[38] Han, Y., Yao, C. B., Cai, Y., Bao, S. B., \& Jiang, G. Q. (2020). Copper decorated ZnO nanowires material: Growth, optical and photoelectrochemical properties. Journal of Alloys and Compounds, 155339.

[39] Li, X., Gao, C., Duan, H., Lu, B., Wang, Y., Chen, L., ... \& Xie, E. (2013). High-performance photoelectrochemical-type self-powered UV photodetector using epitaxial TiO2/SnO2 branched heterojunction nanostructure. Small, 9(11), 2005-2011.

[40] Ababii, N., Hoppe, M., Shree, S., Vahl, A., Ulfa, M., Pauporté, T., ... \& Sontea, V. (2019). Effect of noble metal functionalization and film thickness on sensing properties of sprayed TiO2 ultra-thin films. Sensors and Actuators A: Physical, 293, 242-258.

[41] Neena, D., Kondamareddy, K. K., Humayun, M., Mohan, V. B., Lu, D., Fu, D., \& Gao, W. (2019). Fabrication of $\mathrm{ZnO} / \mathrm{N}-\mathrm{rGO}$ composite as highly efficient visible-light photocatalyst for 2, 4-DCP degradation and H2 evolution. Applied Surface Science, 488, 611619.

[42] Rana, V. S., Rajput, J. K., Pathak, T. K., \& Purohit, L. P. (2020). Influence of N2 flow rate on UV photodetection properties of sputtered $\mathrm{p}-\mathrm{ZnO} / \mathrm{n}-\mathrm{Si}$ heterojuctions. Colloids and Surfaces A: Physicochemical and Engineering Aspects, 586, 124103.

[43] R. Vettumperumal, S. Kalyanaraman, R. Thangavel, Photoconductive UV detectors based heterostructures of $\mathrm{Cd}$ and $\mathrm{Mg}$ doped $\mathrm{ZnO}$ sol gel thin films, Materials Chemistry and Physics 145 (2014) 237-242.

[44] C.-Y. Tsay, S.-H. Yu, Optoelectronic characteristics of UV photodetectors based on solgel synthesized GZO semiconductor thin films, Journal of Alloys and Compounds 596 (2014) $145-150$.

[45] Y.V. Kaneti, J. Moriceau, M. Liu, Y. Yuan, Q. Zakaria, X. Jiang, A. Yu, Hydrothermal synthesis of ternary $\alpha-\mathrm{Fe} 2 \mathrm{O} 3-\mathrm{ZnO}-\mathrm{Au}$ nanocomposites with high gas-sensing performance, Sens. Actuators B Chem. 209 (2015) 88-897. 


\section{Figure captions}

Figure 1: TEM images of pure $\mathrm{ZnO}$ (a) and $\mathrm{Au} / \mathrm{Cu}$ codoped $\mathrm{ZnO}$ (b)

Figure 2: XRD patterns of the pure $\mathrm{ZnO}$ and $\mathrm{Au} / \mathrm{Cu}$ codoped $\mathrm{ZnO}$.

Figure 3: FTIR spectra of pure $\mathrm{ZnO}$ and $\mathrm{Au} / \mathrm{Cu}$ codoped $\mathrm{ZnO}$.

Figure 4: The diffuse reflectance spectra of pure $\mathrm{ZnO}$ (a) and $\mathrm{Au} / \mathrm{Cu}$ codoped $\mathrm{ZnO}$ (b), the band gap of pure $\mathrm{ZnO}$ (c) and $\mathrm{Au} / \mathrm{Cu}$ codoped $\mathrm{ZnO}(\mathrm{d})$.

Figure 5: (a) Schematic representation of the fabrication of $\mathrm{Cu}$ doped $\mathrm{ZnO}$ nanoparticles $\mathrm{UV}$ photodetector, I-V characteristics of Pure $\mathrm{ZnO}$ (b) and $\mathrm{Au} / \mathrm{Cu}$ codoped $\mathrm{ZnO}$ (c) UV PD under dark and UV illumination.

Figure 6: The repeatability of $\mathrm{Au} / \mathrm{Cu}$ codoped $\mathrm{ZnO}$ UV PD.

Figure 7: The variations of responsivity $(\mathrm{R})$ and sensitivity $(\mathrm{S})$ versus the light intensity.

Figure 8: The schematic energy band diagram of pure $\mathrm{ZnO}$ (a) and (b) Energy band diagram of ZnO UV PD decorated with Au NPs illustrating the charge transfer process under UV light illumination.

Table I: Structural parameters calculated from XRD data.

\begin{tabular}{|l|ll|l|l|l|l|}
\hline Sample & $\begin{array}{l}\text { Average } \\
\text { crystallite } \\
\text { diameter } \\
(\mathrm{nm})\end{array}$ & $\begin{array}{l}\text { Lattice parameter } \\
(\mathrm{nm})\end{array}$ & $\begin{array}{l}\text { Unit cell volume } \\
\mathrm{V}\left(\mathrm{A}^{\circ}\right)^{3}\end{array}$ & $\begin{array}{l}\text { Zn-O bond } \\
\text { length }\left(\mathrm{A}^{\circ}\right)\end{array}$ & $\begin{array}{l}\text { Dislocation } \\
\text { density }\left(\mathrm{A}^{\circ}\right)^{-2} \\
\left(10^{-6}\right)\end{array}$ \\
\hline $\mathrm{ZnO}$ & 22 & 3.249 & 5.208 & 47.60 & 1.978 & 8.16 \\
\hline $\begin{array}{l}\mathrm{Au} / \mathrm{Cu} \\
\text { co-doped } \\
\mathrm{ZnO}\end{array}$ & 26 & 3.241 & 5.193 & 47.23 & 1.972 & 9.18 \\
\hline
\end{tabular}


Table II: Comparison of the most important UV photodetector parameters between our wok and others study.

\begin{tabular}{|l|l|l|l|l|l|l|l|}
\hline materials & $\begin{array}{l}\text { Wavelength } \\
(\mathrm{nm})\end{array}$ & $\begin{array}{l}\text { Dark } \\
\text { current } \\
(\mu \mathrm{A})\end{array}$ & $\begin{array}{l}\text { Rise } \\
\text { time } \\
(\mathrm{s})\end{array}$ & $\begin{array}{l}\text { Recovery } \\
\text { time }(\mathrm{s})\end{array}$ & $\begin{array}{l}\text { Responsivity } \\
(\mathrm{A} / \mathrm{W})\end{array}$ & sensitivity & ref \\
\hline $\begin{array}{l}\mathrm{N}-\mathrm{Al} \\
\text { codoped } \\
\mathrm{ZnO}\end{array}$ & 365 & 5.5 & 4 & 5 & 0.1 & 127.2 & 42 \\
\hline $\begin{array}{l}\mathrm{Cd}-\mathrm{La} \\
\text { codoped } \\
\mathrm{ZnO}\end{array}$ & 365 & - & 2.5 & 3 & - & 75 & 36 \\
\hline $\begin{array}{l}\mathrm{Cd} / \mathrm{Mg} \\
\text { doped } \\
\mathrm{ZnO}\end{array}$ & 325 & 0.18 & 5 & 15 & - & 23 & 43 \\
\hline $\begin{array}{l}\mathrm{Doped} \\
\mathrm{ZnO} \text { thin } \\
\text { films }\end{array}$ & $315-400$ & 194 & - & - & - & 15.7 & 44 \\
\hline $\begin{array}{l}\mathrm{Fe} \mathrm{O}_{3-} \\
\mathrm{ZnO}-\mathrm{Au}\end{array}$ & 350 & - & 7 & 17 & - & - & 45 \\
\hline $\begin{array}{l}\mathrm{Au} / \mathrm{Cu} \\
\text { codoped } \\
\mathrm{ZnO}\end{array}$ & 375 & 400 & 1.82 & 1.02 & 0.57 & $10^{3}$ & $\begin{array}{l}\text { Our } \\
\text { work }\end{array}$ \\
\hline
\end{tabular}



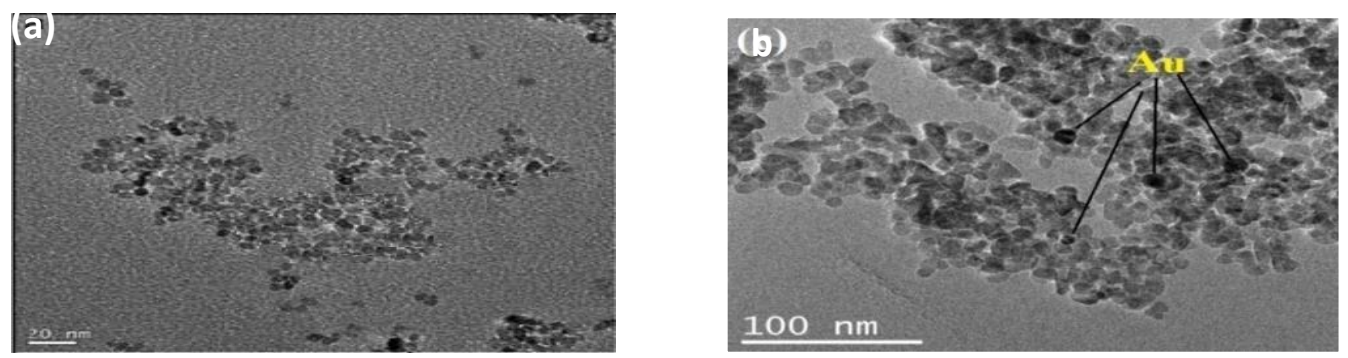

Figure 1

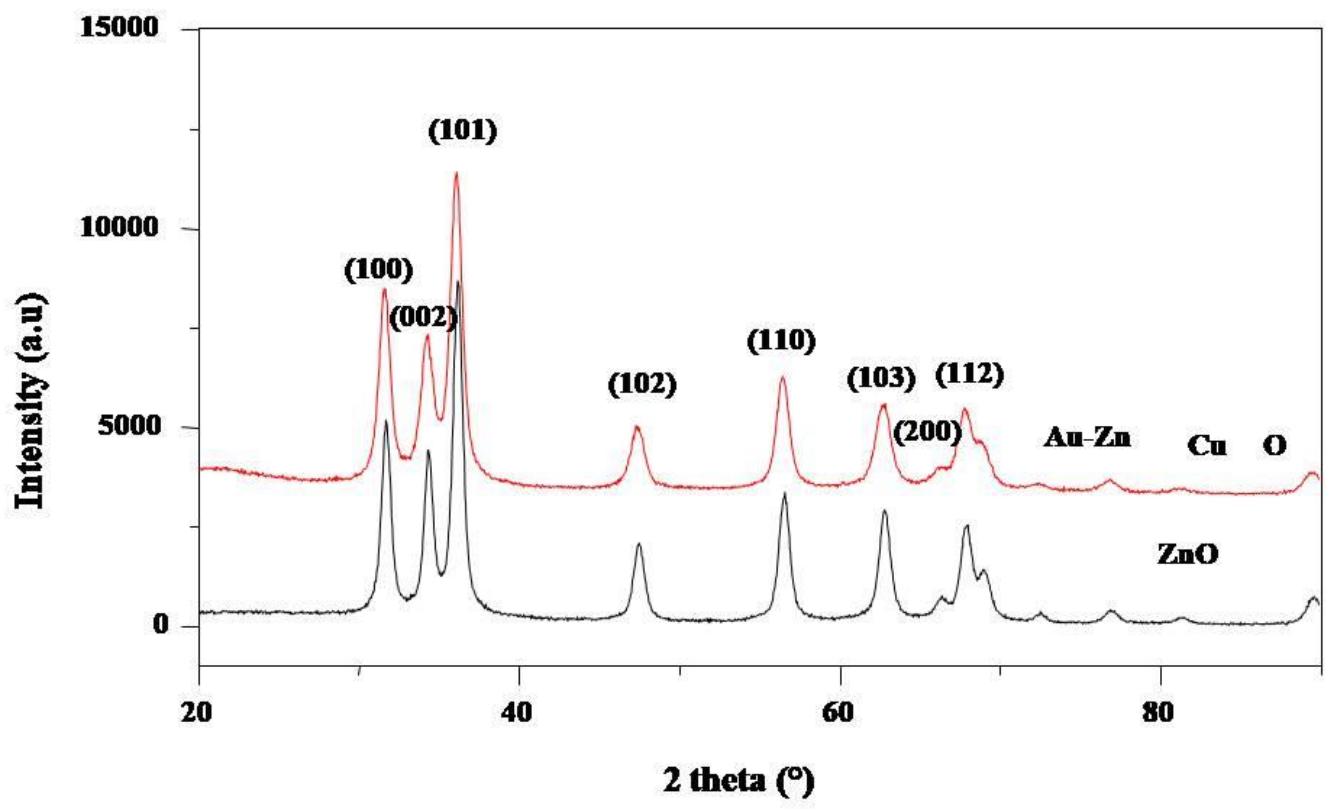

Figure 2 


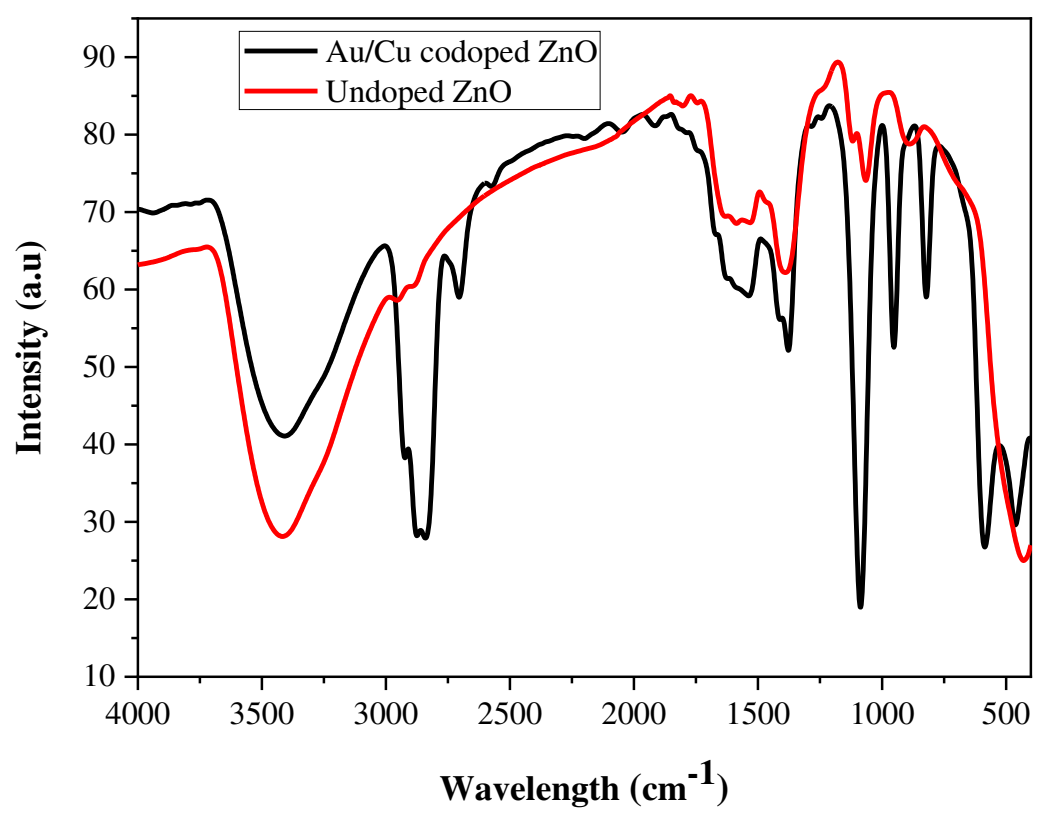

Figure 3 

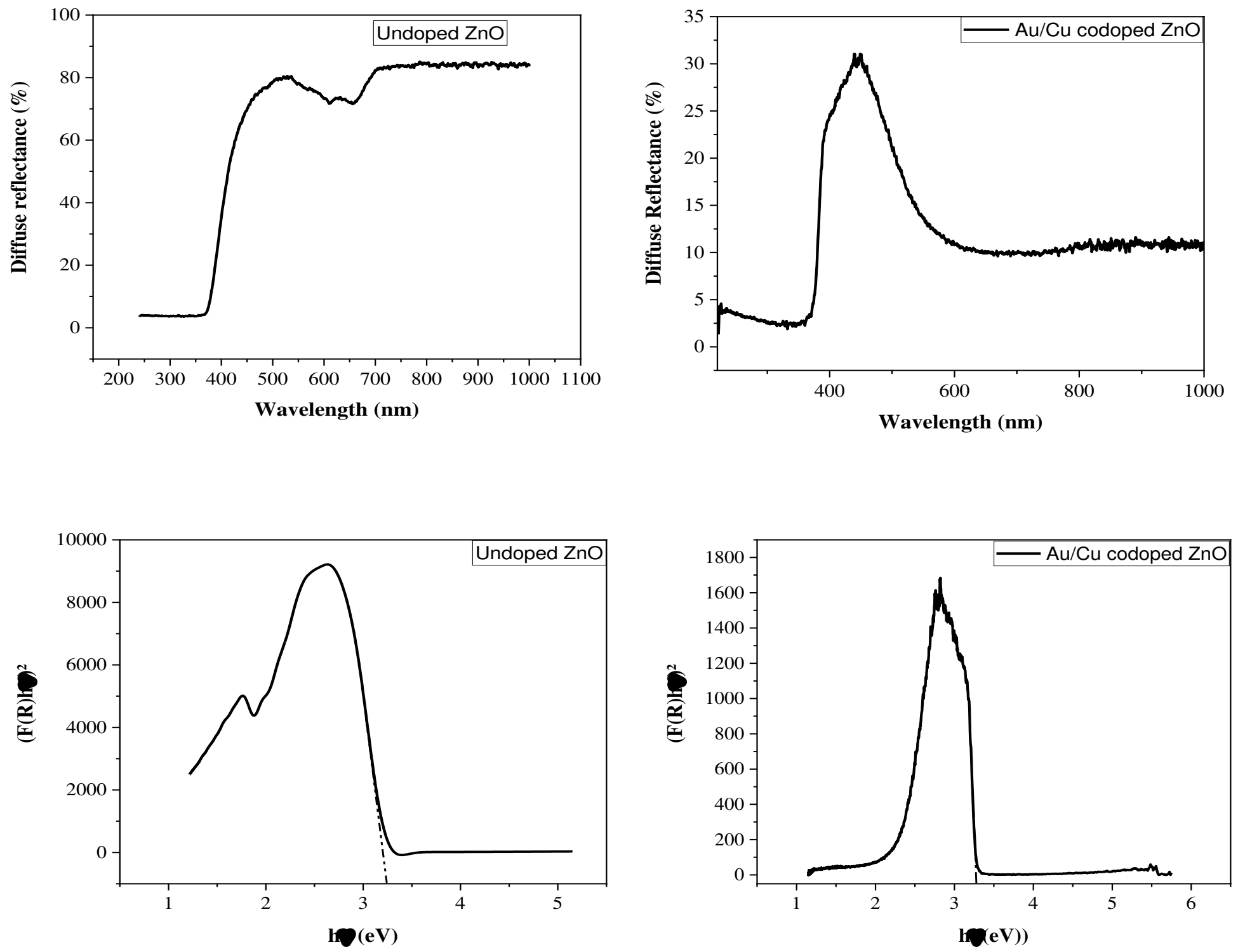

Figure 4 

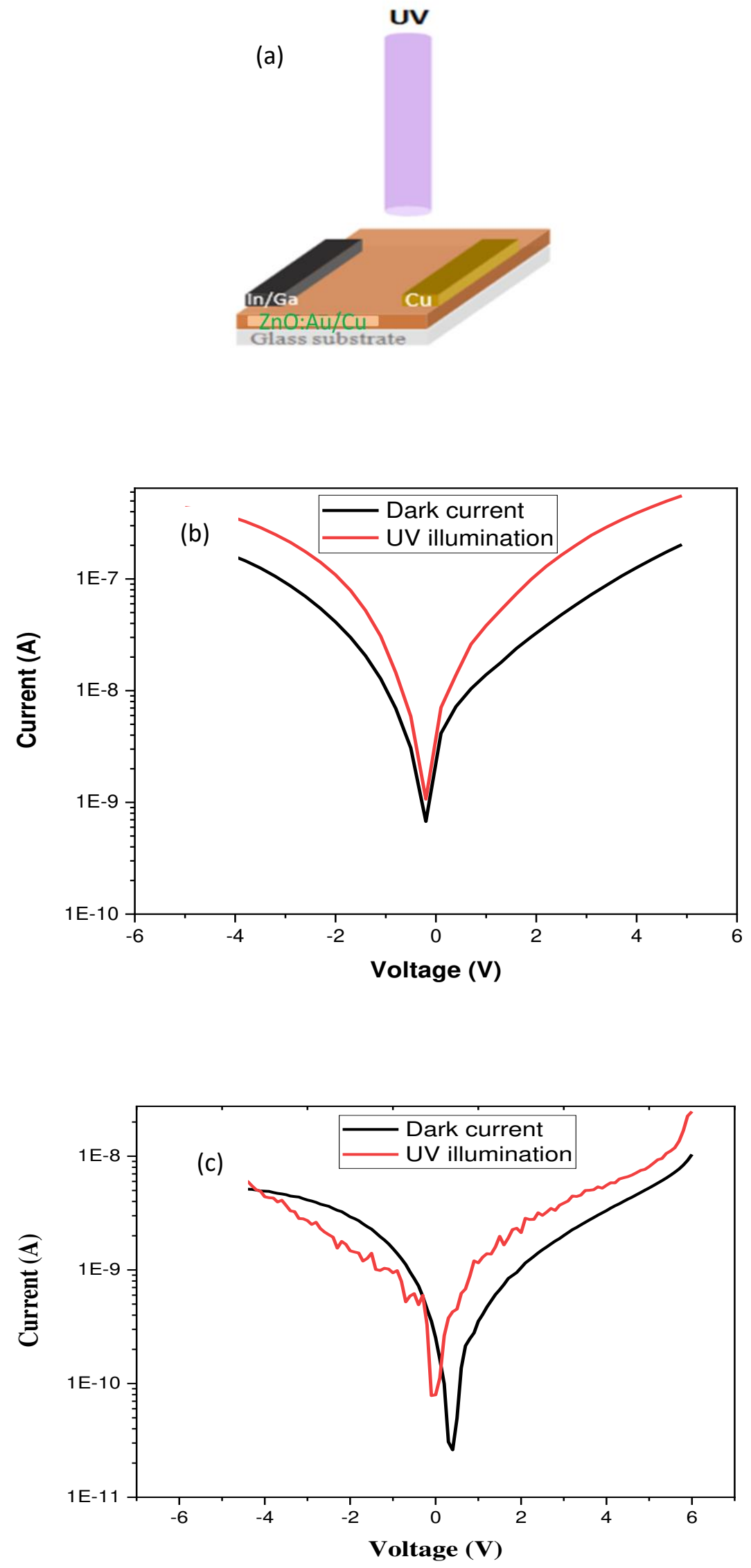

Figure 5 


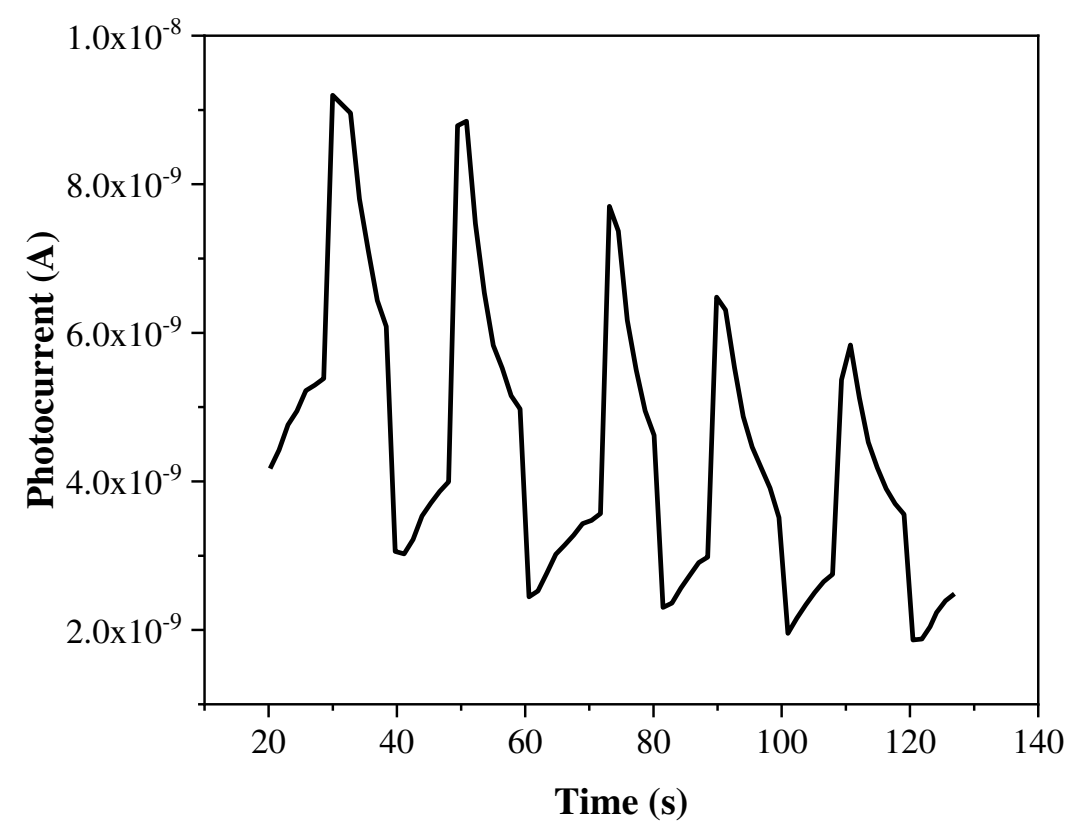

Figure 6 


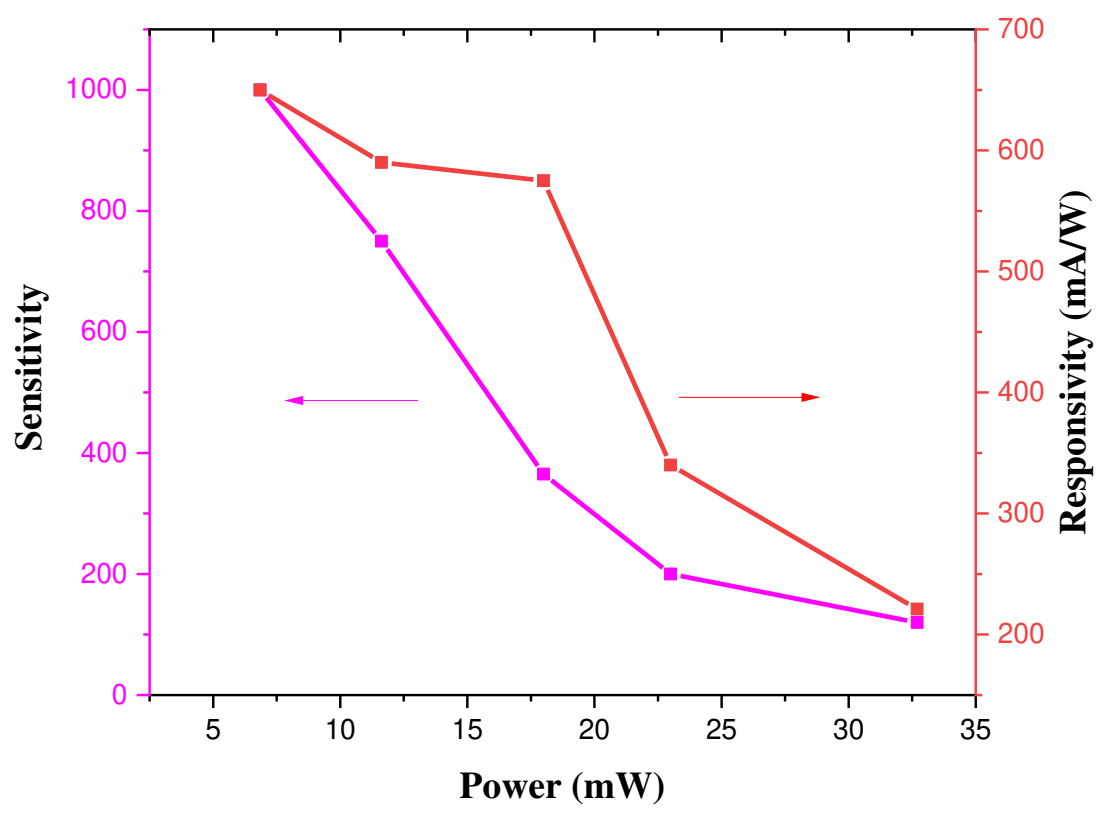

Figure 7 
(a)
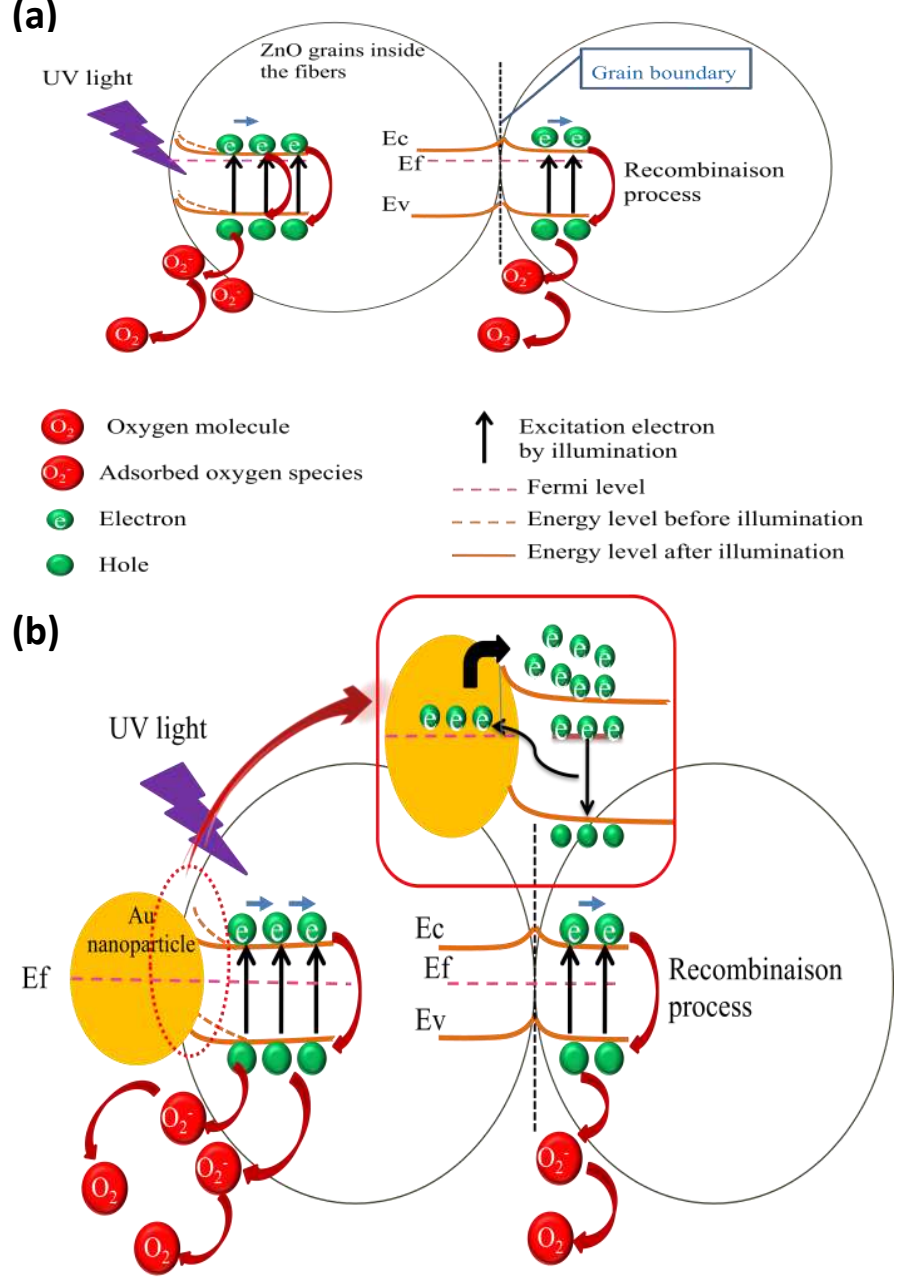

Figure 8 
Figures
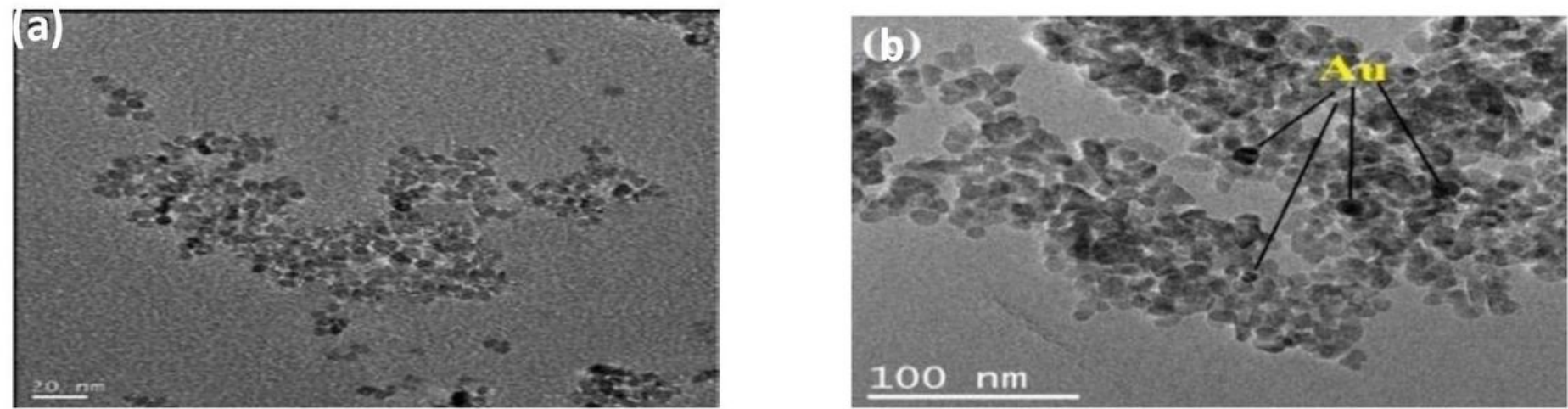

Figure 1

TEM images of pure $\mathrm{ZnO}(\mathrm{a})$ and $\mathrm{Au} / \mathrm{Cu}$ codoped $\mathrm{ZnO}(\mathrm{b})$

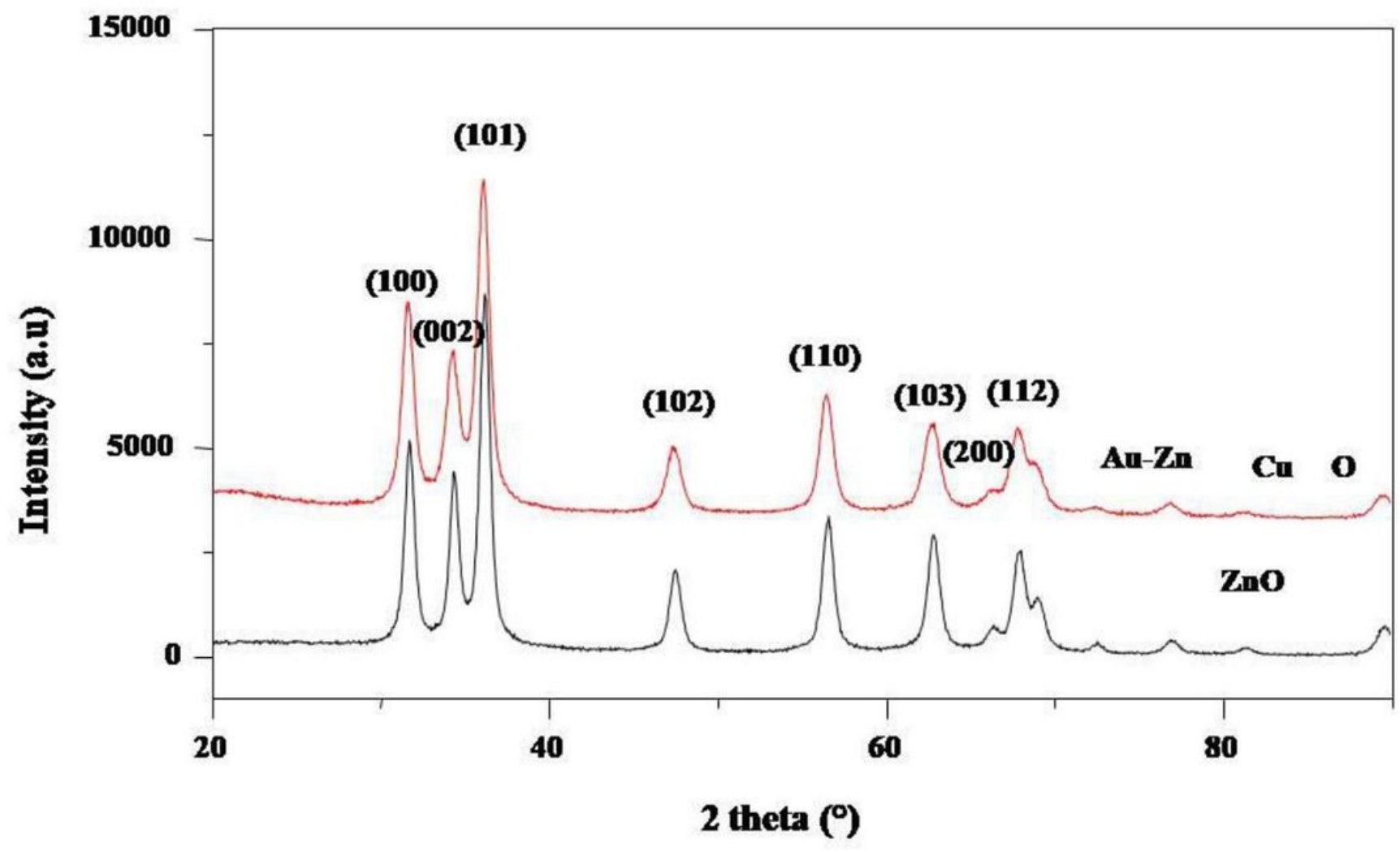

Figure 2

XRD patterns of the pure $\mathrm{ZnO}$ and $\mathrm{Au} / \mathrm{Cu}$ codoped $\mathrm{ZnO}$. 


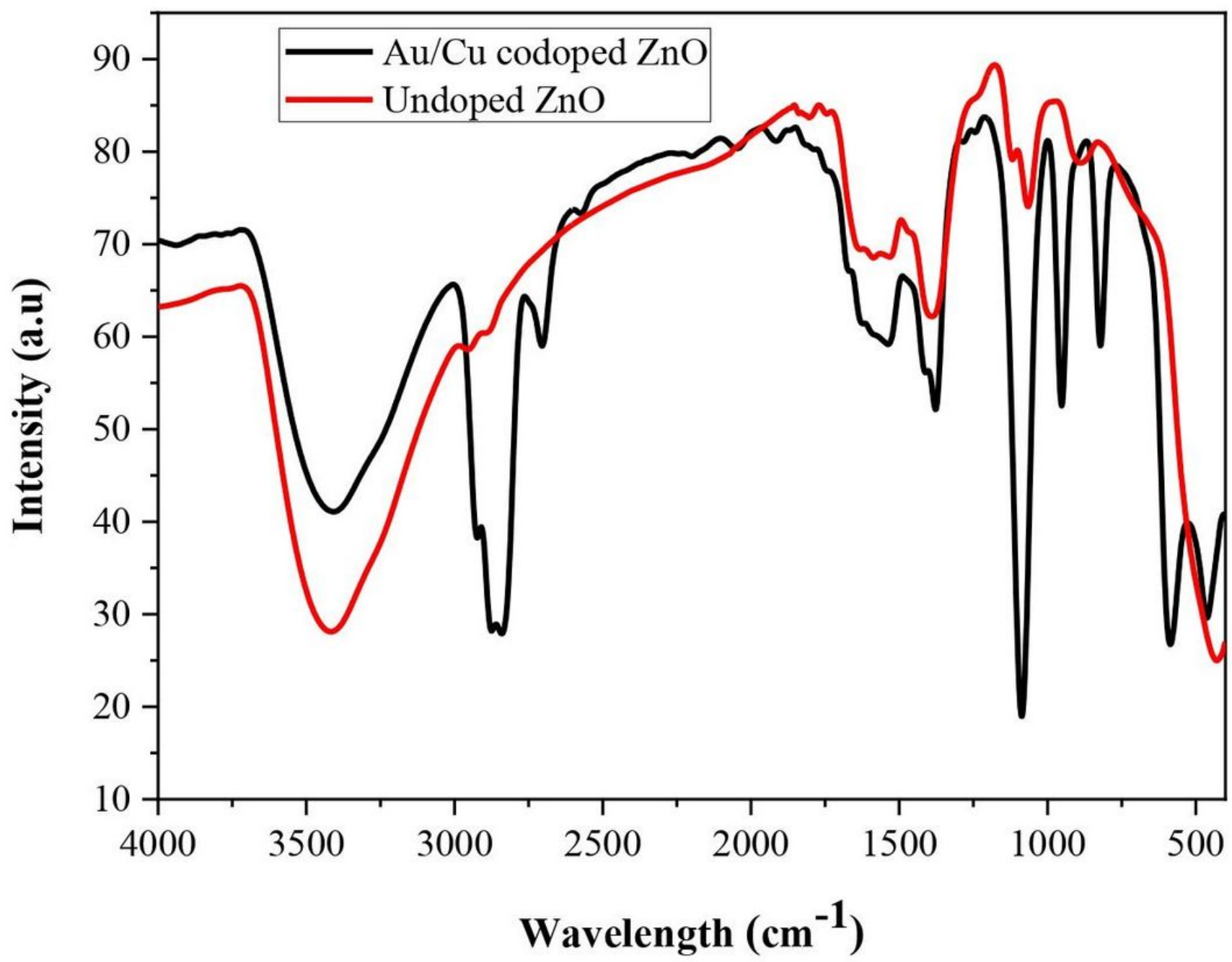

Figure 3

FTIR spectra of pure $\mathrm{ZnO}$ and $\mathrm{Au} / \mathrm{Cu}$ codoped $\mathrm{ZnO}$. 

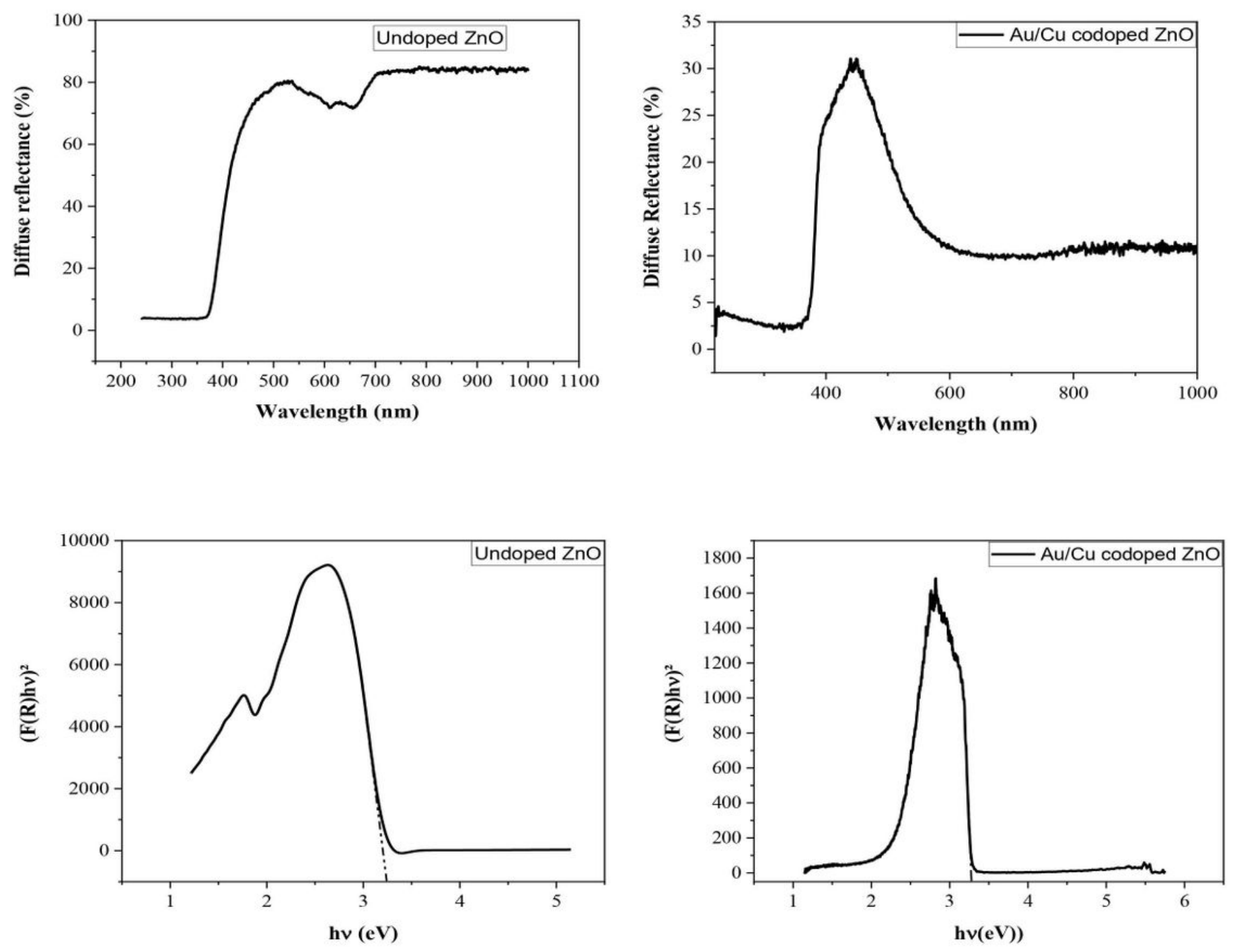

Figure 4

The diffuse reflectance spectra of pure $\mathrm{ZnO}(\mathrm{a})$ and $\mathrm{Au} / \mathrm{Cu}$ codoped $\mathrm{ZnO}$ (b), the band gap of pure $\mathrm{ZnO}$ (c) and $\mathrm{Au} / \mathrm{Cu}$ codoped $\mathrm{ZnO}$ (d). 

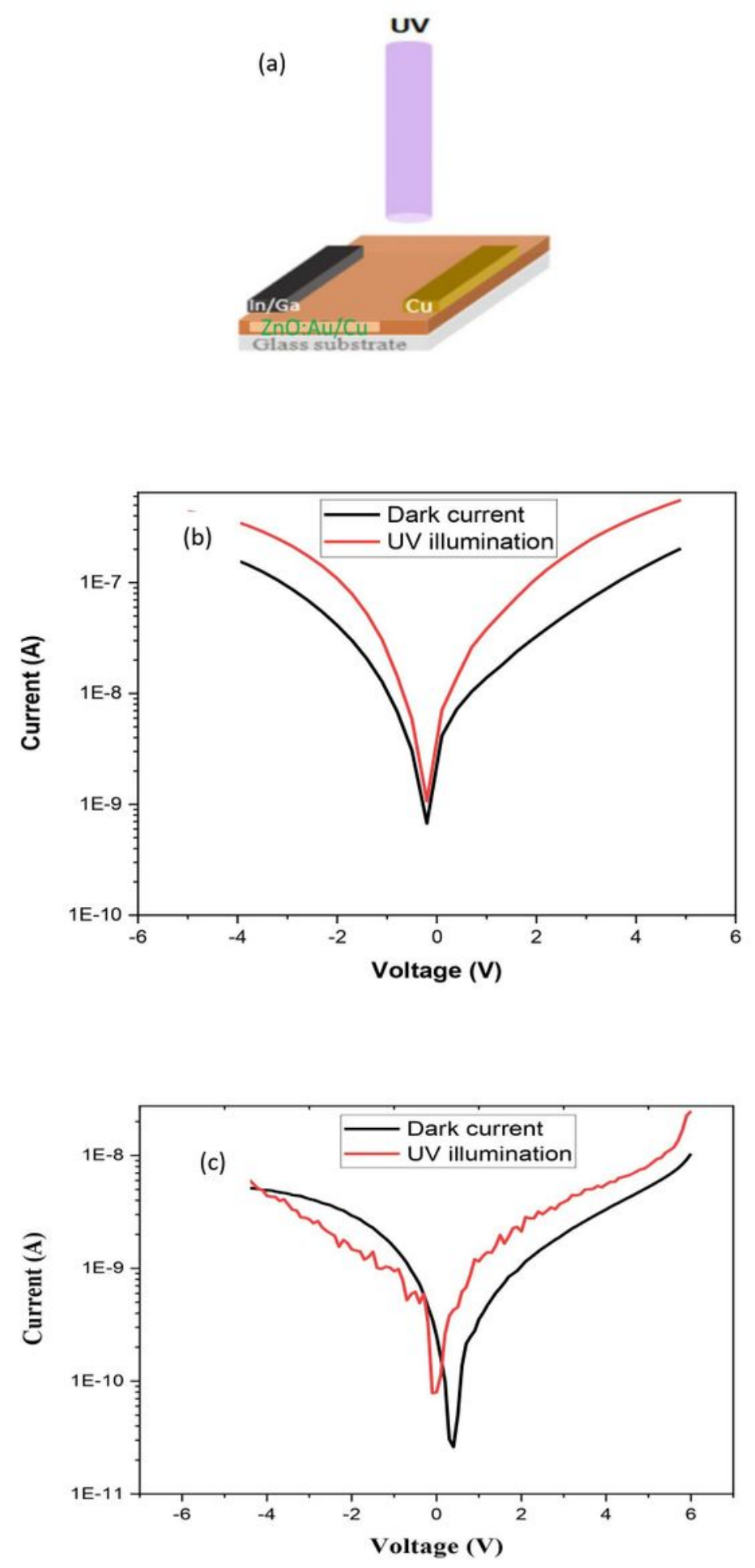

Figure 5

(a) Schematic representation of the fabrication of Cu doped ZnO nanoparticles UV photodetector, I-V characteristics of Pure ZnO (b) and Au/Cu codoped ZnO (c) UV PD under dark and UV illumination. 


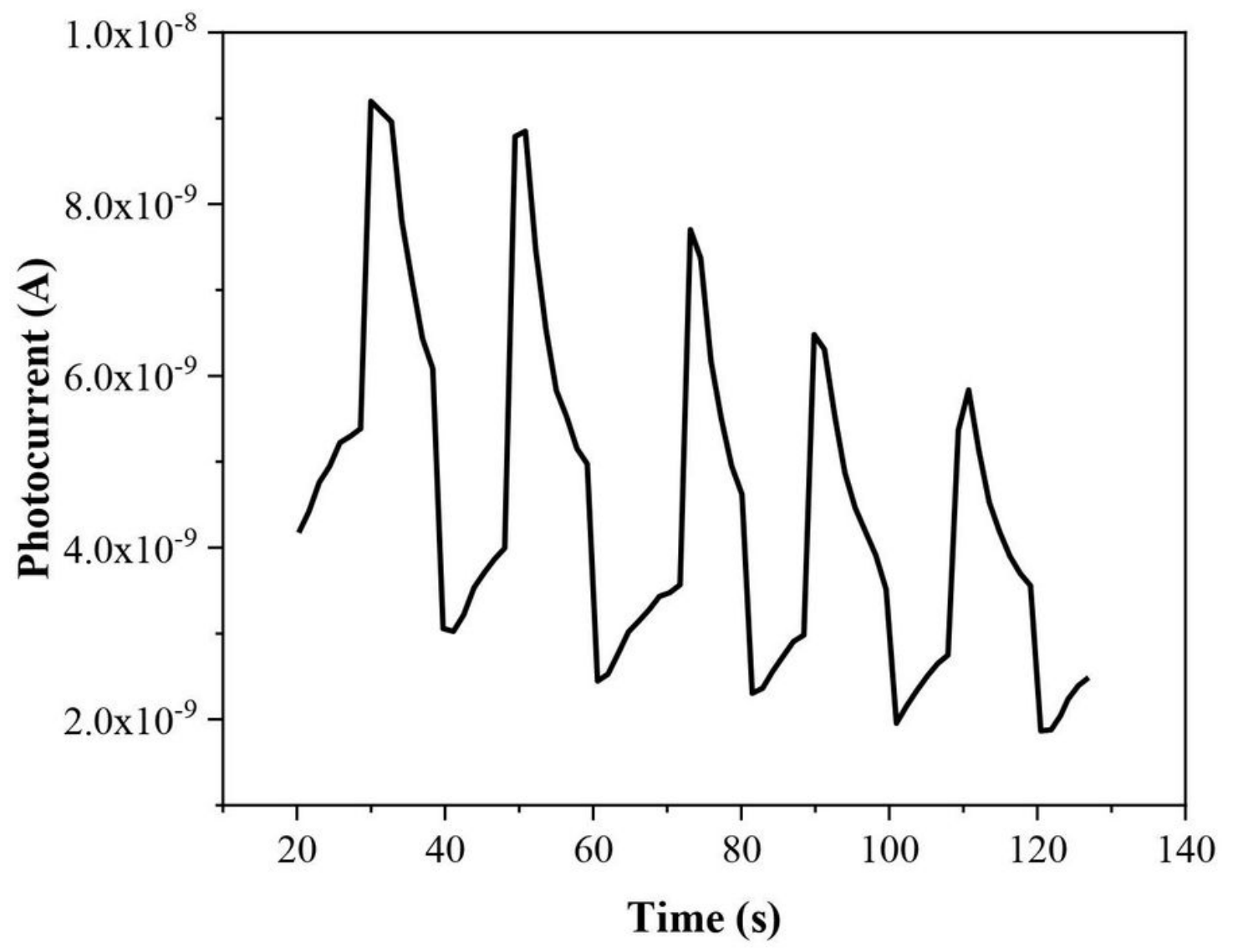

Figure 6

The repeatability of $\mathrm{Au} / \mathrm{Cu}$ codoped $\mathrm{ZnO}$ UV PD. 


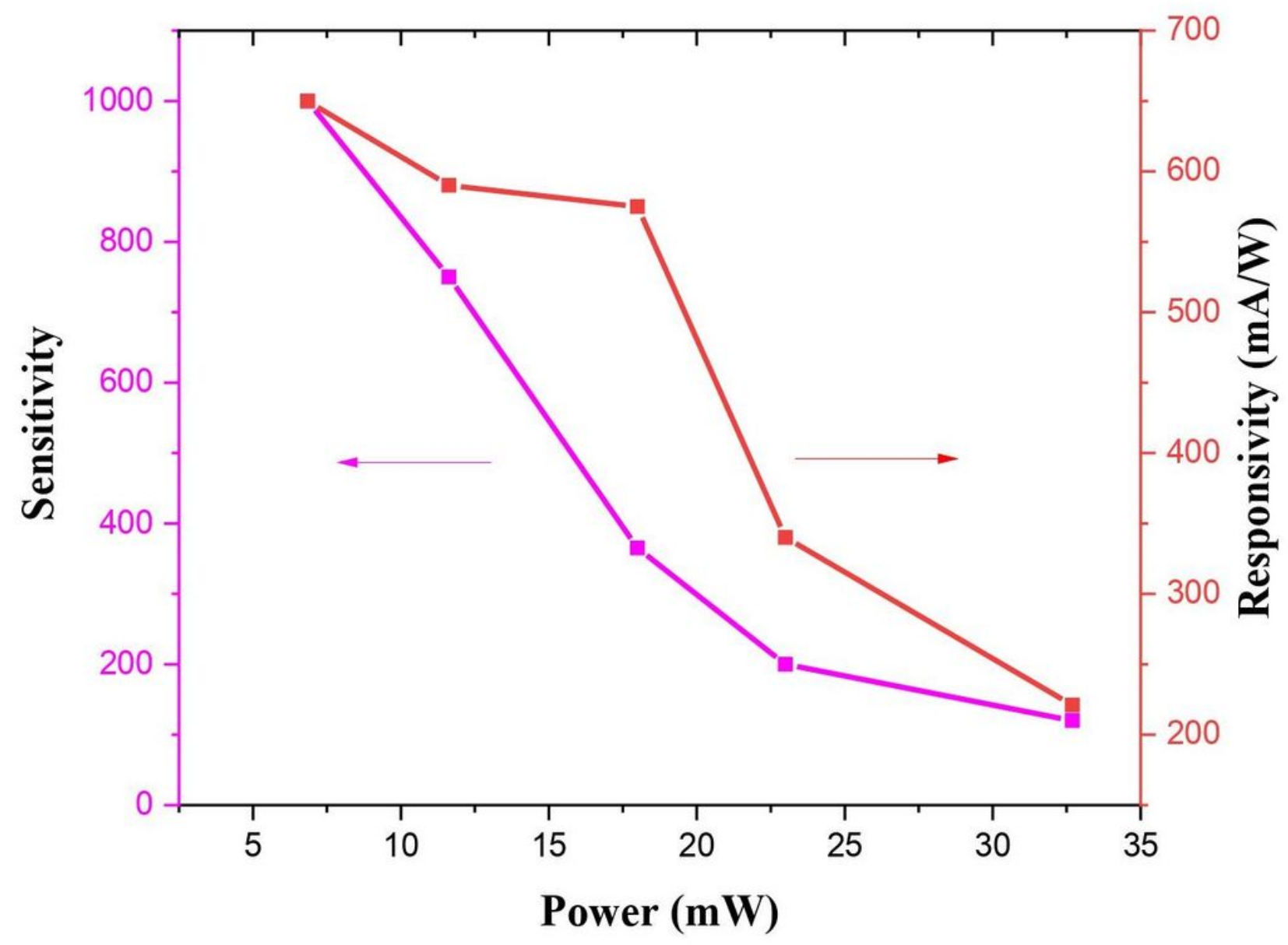

Figure 7

The variations of responsivity $(R)$ and sensitivity $(S)$ versus the light intensity. 
(a)

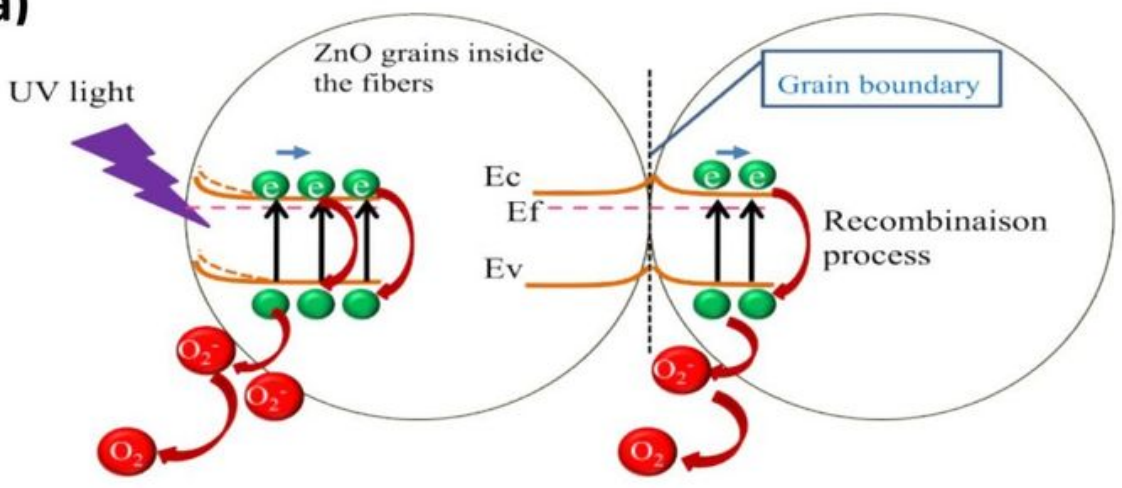
$\mathrm{O}_{2}$ Oxygen molecule
$\uparrow \begin{aligned} & \text { Excitation electron } \\ & \text { by illumination }\end{aligned}$
$\mathrm{Q}_{2}$ Adsorbed oxygen species by illumination level
(e) Electron
_. - - Energy level before illumination
Hole Energy level after illumination

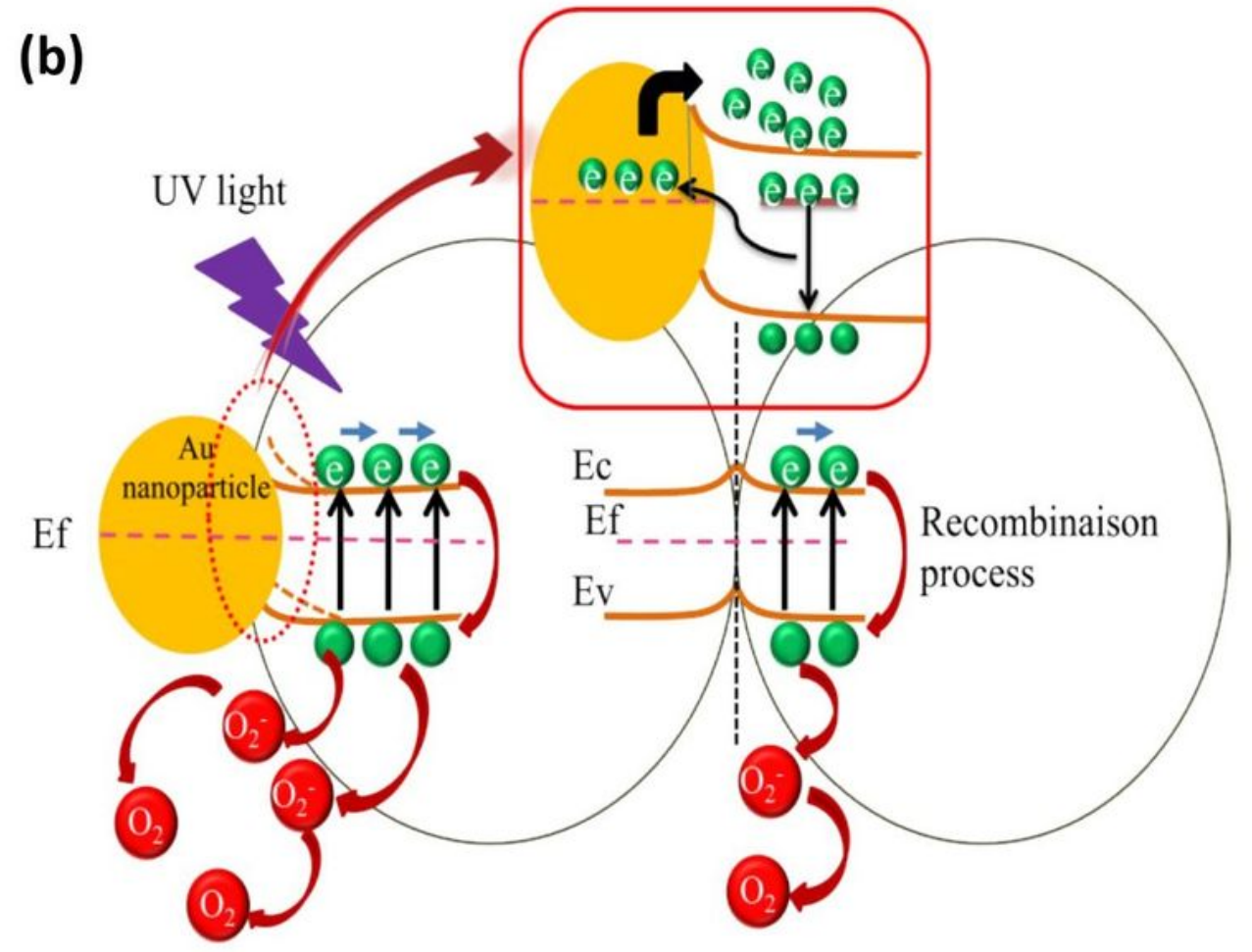

\section{Figure 8}

The schematic energy band diagram of pure ZnO (a) and (b) Energy band diagram of ZnO UV PD decorated with Au NPs illustrating the charge transfer process under UV light illumination. 